\title{
Growth and yield of several rice varieties in swampland agroecosystems in Mesuji Regency, Lampung Province
}

\author{
Slameto*, Meidaliyantisyah, and Arfi Irawati \\ Lampung Assessment Institute for Agricultural Technology, Jl. Hi. Zainal Abidin Pagar Alam No.1A, \\ Rajabasa, Bandar Lampung, Lampung Province, Indonesia, 35145
}

\begin{abstract}
Swampland agroecosystem is a potential area for rice extensification program in order to increase food production. This study aimed to examine the growth and yield of several rice varieties planted in swampland agroecosystems in Mesuji Regency, Lampung Province. The experiment was conducted from November 2020 until March 2021.. The planting location was in Tanjung Mas Jaya Village, Mesuji Timur District, Mesuji Regency, Lampung Province. The rice varieties planted were IAARD's Superior varieties (Cilamaya Muncul, Inpara-2, Inpara-8, and Inpari IR Nutrizinc), multinational varieties (Mapan and Supadi) and existing local variety (Kebo). The observed variables were components of the growth and production of rice plants. The data were analyzed using Duncan test. The results showed that the yield was significantly different between the rice varieties planted. The lowest rice yield was obtained from the Inpara-2 variety ( 7.573 ton ha ${ }^{-1}$ of HDG). The highest yield of rice was in the Kebo variety (10.400 ton ha ${ }^{-1}$ of HDG). In order to gain optimal rice production in an area, it is necessary to use superior varieties of rice that have been adaptive to the local area.
\end{abstract}

\section{Introduction}

Rice is a mainstay commodity to fulfill the food needs of Indonesian people. Along with the continued increase in population for staple foods, rice production also needs to be increased. There are various programs to support the efforts to increase rice production, such as intensification of production and expansion of planted areas These are the core lead to food self-sufficiency in national and regional scale, as well as in Lampung Province which strongly supports these efforts.

The efforts to increase rice production is directed not only through cropping index enhancement but also the expansion of planting area which is closely related to the potential of land in the Lampung region. The results from the delineation of the Lampung agro-ecological zone on a scale of 1:250,000 by the Indonesian Agency for Agricultural Research and Development (IAARD) [1] have identified that the recommended land area

\footnotetext{
*Corresponding author: islameto@yahoo.co.id
} 
for agriculture, both annual crops and food crops, is estimated at 2.7 million ha out of 3.4 million ha in Lampung's total area.

The technically irrigated rice fields covering an area of about 445,173 ha, while the potential land for rainfed rice field in Lampung is quite extensive with the estimation at 121,049 ha [2] or about $27 \%$ of Lampung's total rice fields [1]. The land can be classified as sub-optimal land due to limited soil fertility and the availability of rainwater. The Central Statistics Agency of Lampung Province stated that the area of unirrigated rice fields in Lampung is around 197.343 ha with a cropping index (CI) once a year [2]. According to Hafif [3], the productivity of rainfed lowland rice in Lampung tends to vary from the range of 3-7 tons/ha. However, the land still has the potential to become rice production land with an increase in the cropping index.

In addition to these two types of land, the tidal swamp agro-ecosystem is an alternative for expanding rice fields as an effort to increase food production. The choice of technological innovation in the form of using superior rice varieties can increase rice productivity. Several types of new rice varieties are suitable to be planted in swampland agro-ecosystems. Although extreme environmental factors in the form of drought or flooding due to tidal sea water up to 1-2 months after the previous season's rice harvest is a challenge in tidal swamp land. In addition, the limitations of labor and capital as well as the extent of cultivated rice fields per farmer's household are often a barrier to farmers' efforts to increase the intensity of planting (CI) of swampland from one to two [4].

Tidal swamp land is known as problematic and fragile land. In the tidal area there are two main types of soil, which are mineral and peat soil [5]. The fragility of tidal land is from the presence of a pyrite layer and weak soil support. These made thenutrients' cation are easily lost and washed out [6].

Tidal swampland can be used as agricultural land, but the yield is very dependent on how it is managed. For this reason, farmers need to understand the nature and conditions of soil and water in tidal swampland. These are related to acid sulfate soils with their pyrite compounds, peat soils, large and small tides, groundwater depth, and the acidity of water that inundates the land $[6,7,8]$.

There are four typologies of tidal land, which are: 1) potential land, which is land that has a depth of pyrite (toxic layer) of $>50 \mathrm{~cm}$ from the ground surface; 2) acid sulphate land, which is land with a layer of pyrite at a depth of $0-50 \mathrm{~cm}$ from the soil surface; 3) Peatland, which is land contains layers of peat with varying depths, and 4) Saline land, which is land that gets seawater intrusion so that it contains high concentrations of salt, especially during the dry season [9].

Appropriate technology that has been studied and applied in tidal swampland is ratoon technology. This technology can increase rice production in swampland [10], increase farmers' resilience to climate change [11], reduce costs [12]. The advantages of implementing ratoon rice cultivation in swampland include: 1) reduce production costs because there is no need for tillage and replanting, 2) reduce fertilizer ( $1 / 2$ than the dose given to the first plant), 3) shorter harvest life, 4) yields can reach 66 percent of the main crop [13], and 5) plants in the ratoon system use $60 \%$ less water than the main crop [14].

However, from the results of research by Susilawati et al. [15] and Sinaga et al. [16] that new varieties of rice are needed to provide optimal ratoon yields in tidal swampland and able to contribute more than $60 \%$ yield of the main crop. Tidal rice in Indonesia yield at 3.2 $-4.2 \mathrm{t} / \mathrm{ha}$ with a harvest age of $5-6$ months. With the innovation of ratoon rice from a new type of rice, the yield will be achieved at least $2 \mathrm{t} /$ ha within 2 months.

Mesuji Regency is one of the areas in Lampung Province which has very potential tidal swampland type B. The tidal swampland is the foundation of future food security because there is quite a large area but only a few have been used and the availability of water is relatively sufficient during the dry season. Based on this, the optimalization of tidal 
swampland for food production is very urgent. One way to do this is by implementing appropriate innovations for specific locations. These specific technological innovations include planting adaptive rice varieties in tidal swampland in the Mesuji area. For this reason, this study aims to examine the yield and characteristics of several swampland rice varieties planted in swamp agroecosystems in the Mesuji Regency, Lampung.

\section{Materials and methods}

The study was conducted on the rice field in tidal swampland type B agro-ecosystem in Mesuji Regency in 2021. This experiment was conducted from November 2020 up to April 2021 in Tanjung Mas Jaya Village, East Mesuji District, Mesuji Regency, Lampung Province. Four IAARD superior rice varieties (Cilamaya Muncul, Inpara-2, Inpara-8, Inpari IR Nutrizinc), two varieties from multinational companies (Mapan, Supadi), and one local variety (Kebo) were tested in this experiment. Cultivation practices consist of the use of rice seedlings aged $<21$ days after sowing, 1 seed per planting hole, 2:1 row legowo planting technic, urea $150 \mathrm{~kg} \mathrm{ha}^{-1}, \mathrm{SP}-36100 \mathrm{~kg} \mathrm{ha}^{-1}$, and $\mathrm{KCl} 75 \mathrm{~kg} \mathrm{ha}^{-1}$.

The data observed including vegetative stage variables (plant height, number of leaves), and generative stage variables related to the yield components of rice. Data analysis was performed by analysis of variance (ANOVA) and continued with Duncan's test. Data are presented using descriptive statistics.

\section{Results and discussion}

Table 1 shows vegetative and generative growth of different varieties tested in swampland areas of Mesuji Regency. The results of the analysis of rice plants' height showed significant differences in Duncan's test $\alpha=5 \%$. The test results showed that the Supadi variety gave the highest plant height $(95.27 \mathrm{~cm})$. Meanwhile, the appearance of Inpara-2 and Inpara-8 varieties gave relatively lower plant height compared to other varieties. This condition is closely related to the morphological and physiological characteristics of the variety which has a different appearance for each variety, especially from the crosses of its parents, in accordance with the purpose of producing the variety [17]. In addition, the types of product varieties of the Indonesian Agency for Agricultural Research and Development (Cilamaya Muncul, Inpara-2, Inpara-8, Inpari IR Nurtizinc) are inbred rice types that are very different from hybrid rice (Supadi and Mapan).

Tabel 1. Vegetative and generative growth stage component on several Superior rice varieties in Mesuji Regency's swampland in 2021.

\begin{tabular}{|c|c|c|c|c|c|c|c|}
\hline Variety & $\begin{array}{c}\text { Plant } \\
\text { height } \\
(\mathbf{c m})\end{array}$ & $\begin{array}{c}\text { Number } \\
\text { of tillers }\end{array}$ & $\begin{array}{c}\text { Number of } \\
\text { productive } \\
\text { tillers }\end{array}$ & $\begin{array}{c}\text { Panicle } \\
\text { length } \\
\text { (cm) }\end{array}$ & $\begin{array}{c}\text { Number } \\
\text { of full } \\
\text { grain }\end{array}$ & $\begin{array}{c}\text { Number } \\
\text { of empty } \\
\text { grain }\end{array}$ & $\begin{array}{c}\text { Number of } \\
\text { clumps per } \\
\text { sample area }\end{array}$ \\
\hline $\begin{array}{c}\text { Cilamaya } \\
\text { Muncul }\end{array}$ & $83.80^{\mathrm{c}}$ & $16.87^{\mathrm{a}}$ & $16.47^{\mathrm{a}}$ & $26.46^{\mathrm{b}}$ & $157.67^{\mathrm{cd}}$ & $21.20^{\mathrm{ab}}$ & $110.00^{\mathrm{cd}}$ \\
\hline Inpara 2 & $76.80^{\mathrm{a}}$ & $40.93^{\mathrm{e}}$ & $38.13^{\mathrm{e}}$ & $24.75^{\mathrm{a}}$ & $130.87^{\mathrm{ab}}$ & $18.40^{\mathrm{a}}$ & $74.67^{\mathrm{b}}$ \\
\hline Inpara 8 & $78.60^{\mathrm{a}}$ & $35.87^{\mathrm{d}}$ & $34.00^{\mathrm{d}}$ & $24.59^{\mathrm{a}}$ & $166.27^{\mathrm{cd}}$ & $16.93^{\mathrm{a}}$ & $66.00^{\mathrm{ab}}$ \\
\hline $\begin{array}{c}\text { IR } \\
\text { Nutrizinc }\end{array}$ & $81.00^{\mathrm{b}}$ & $23.40^{\mathrm{b}}$ & $22.93^{\mathrm{b}}$ & $24.29^{\mathrm{a}}$ & $116.87^{\mathrm{a}}$ & $21.40^{\mathrm{ab}}$ & $89.67^{\mathrm{bc}}$ \\
\hline Mapan & $86.53^{\mathrm{d}}$ & $26.13^{\mathrm{c}}$ & $26.07^{\mathrm{c}}$ & $27.88^{\mathrm{b}}$ & $179.27^{\mathrm{d}}$ & $19.93^{\mathrm{ab}}$ & $48.00^{\mathrm{a}}$ \\
\hline Supadi & $95.27^{\mathrm{f}}$ & $22.47^{\mathrm{b}}$ & $22.07^{\mathrm{b}}$ & $27.40^{\mathrm{b}}$ & $149.73^{\mathrm{bc}}$ & $28.00^{\mathrm{bc}}$ & $90.33^{\mathrm{bc}}$ \\
\hline Kebo & $90.20^{\mathrm{c}}$ & $22.07^{\mathrm{b}}$ & $21.47^{\mathrm{b}}$ & $23.77^{\mathrm{a}}$ & $166.33^{\mathrm{cd}}$ & $30.93^{\mathrm{c}}$ & $120.67^{\mathrm{d}}$ \\
\hline
\end{tabular}

Note: numbers followed by the same letter in each column do not show a significant difference in Duncan's test at $5 \%$ level 
The analysis result of the number of tillers and the number of productive tillers showed that the Inpara-2 variety gave the highest total number of tillers (40.93 stems) and productive tillers (38.13 stems). The percentage of productive tillers that produced panicles and grains of rice compared to the total tillers that could be produced was $93.15 \%$. This showed that the ability of the Inpara-2 rice variety to produce tillers is higher than the other varieties. The increase in the number of tillers is one indicator of the performance of rice plants to achieve maximum productivity. The increase in the number of tillers in the vegetative vase will increase with the age of the plant. However, not all rice tillers can grow and develop normally and become productive tillers. Rice tillers that lose in the competition for nutrients, light and growth will die, and if they can survive their growth will not be normal and will not produce. For the variable number of tillers, both the total number of tillers and productive tillers showed a significant difference in Duncan's test at 5\%.

In the aspect of generative growth in the form of panicle length, it showed that the resulting panicle has a length that is similar in size. The panicle length variable showed a significant difference in Duncan's test at 5\%. The highest panicle length tends to be produced from hybrid varieties of rice, which is Mapan $(27.88 \mathrm{~cm})$ and Supadi $(27.40 \mathrm{~cm})$. This condition was the characteristics of these two varieties which are hybrid varieties,. Inbred varieties (Cilamaya Muncul, Inpara 2, Inpara-8, and IR Nutrizinc) are relatively shorter in size than panicle length.

The analysis of the number of full grains per panicle showed significant differences between various treatments of varieties in Duncan's test at $5 \%$. The number of full grain ranged from 116.87-179.27 grains per panicle, which means that the amount of grain produced was very varied. The highest number of rice grains was produced from the Mapan rice variety (179.27 grains) while the lowest was from the Inpari IR Nutrizink rice variety (116.87 grains). This difference is possible because of the different types of rice, inbred and hybrid.

In contrast to the number of full grains, the highest number of empty grains was produced by the local variety Kebo (30.93) while the lowest number of empty grains was obtained from the inbred rice variety, Inpara-8 (16.9). This indicates the IAARD varieies tend to be able to minimize the occurrence of empty grain, which means that their reproductive power tends to be quite high from the results of pollinating rice plants when they are in the early generative phase. The analysis of the number of empty grains per panicle showed significant differences among varieties based on Duncan's test at 5\%.

In the analysis of the number of clumps per sample are, it showed significant differences among varieties in Duncan's test $=5 \%$. The number of clumps per sample are shows a reflection of the growth power of a plant from the start on how strong its growth power is. IT is the reflection of the plant population that can be harvested. The highest number of clumps per sample are was produced from the Kebo rice variety (120.67). While the lowest number of clumps per sample area occurred in the Mapan variety (48.00).

The results of the analysis of the number of grains per panicle showed a significant difference at the $5 \%$ Duncan test. The number of grains per panicle is one indicator of the production of a rice plant where a high number of grains per panicle certainly results in high rice production. The number of grains per panicle shows the average grain that can be produced per one unit of rice panicle. The highest number of grains per panicle was obtained from the Mapan variety (199.20 grains) and the lowest was obtained from the Inpari IR Nutrizinc variety (138.27 grains). This showed that rice varieties of hybrid types significantly provide differences in the appearance of generative growth which tend to be more optimal. As for Kebo, an inbred variety, that also tends to have higher value in some of the vagetative and generative components, has been adapted well in this agroecosystem. 
Tabel 2. Yield component of several superior rice varieties in Mesuji District's swampland in 2021

\begin{tabular}{|c|c|c|c|c|c|}
\hline Varietas & $\begin{array}{c}\text { Number of grain } \\
\text { per panicle }\end{array}$ & $\begin{array}{c}\text { Grain weight } \\
\text { per panicle (g) }\end{array}$ & $\begin{array}{c}\text { 100-grain } \\
\text { weight (g) }\end{array}$ & $\begin{array}{c}\text { Grain weight per } \\
\text { sample area (g) }\end{array}$ & $\begin{array}{c}\text { Yield } \\
\text { (kg.ha }^{-1} \text { ) }\end{array}$ \\
\hline $\begin{array}{c}\text { Cilamaya } \\
\text { Muncul }\end{array}$ & $178.87^{\mathrm{b}}$ & $5.434^{\mathrm{bc}}$ & $3.147^{\mathrm{c}}$ & $5920.00^{\mathrm{b}}$ & $9472^{\mathrm{b}}$ \\
\hline Inpara 2 & $149.27^{\mathrm{a}}$ & $2.661^{\mathrm{a}}$ & $2.475^{\mathrm{a}}$ & $4733.33^{\mathrm{a}}$ & $7573^{\mathrm{a}}$ \\
\hline Inpara 8 & $183.20^{\mathrm{b}}$ & $5.474^{\mathrm{bc}}$ & $3.213^{\text {ed }}$ & $5896.67^{\mathrm{b}}$ & $9431^{\mathrm{b}}$ \\
\hline Nutrizinc & $138.27^{\mathrm{a}}$ & $3.297^{\mathrm{a}}$ & $2.586^{\mathrm{a}}$ & $5058.33^{\mathrm{a}}$ & $8093^{\mathrm{a}}$ \\
\hline Mapan & $199.20^{\mathrm{b}}$ & $6.117^{\mathrm{c}}$ & $3.389^{\mathrm{de}}$ & $6365.00^{\mathrm{b}}$ & $10184^{\mathrm{b}}$ \\
\hline Supadi & $177.73^{\mathrm{b}}$ & $5.490^{\mathrm{bc}}$ & $3.511^{\mathrm{e}}$ & $5966.67^{\mathrm{b}}$ & $9547^{\mathrm{b}}$ \\
\hline Kebo & $197.27^{\mathrm{b}}$ & $4.983^{\mathrm{b}}$ & $2.899^{\mathrm{b}}$ & $6500.00^{\mathrm{b}}$ & $10400^{\mathrm{b}}$ \\
\hline
\end{tabular}

Source: field data, 2021. Note: numbers followed by the same letter in each column do not show a significant difference in Duncan's test at 5\% level

The results of the analysis of the grain weight per panicle also showed a significant difference at the 5\% Duncan test. Grain weight per panicle can also be an indicator of the production of a rice plant where high grain weight per panicle certainly results in high rice production. Grain weight per panicle shows the average weight of a grain that can be produced per one unit of rice panicle produced. The highest grain weight per panicle was obtained from the Mapan variety $(6.117 \mathrm{~g})$ and the lowest was obtained from the Inpara-2 variety $(2.661 \mathrm{~g})$. This also indicates that the hybrid rice varieties are significantly superior.

The weight of 100 grains is closely related to the morphological performance of a plant component, whether the type is long, short, round and so on. The results of the analysis of the weight of 100 grains showed significant differences in several rice varieties grown on Duncan's test level at 5\%. The highest weight of 100 grains was obtained from the Supadi rice variety $(3.511 \mathrm{~g})$ which means that the grain size was quite large. Meanwhile, the lowest weight of 100 grains was produced by the Inpara 2 variety $(2.475 \mathrm{~g})$. This condition is thought to be related to the condition of varieties that have just begun to be introduced, especially for inbred varieties such as Inpara.

This result also showed local variety (Kebo) gave the highest rice yield compared to other varieties. It seems that crop yield was determined by the adaptability of the variety to agroecological conditions. Kebo variety has been adapted to the local conditions. On the other hand, Inpara 2 and Inpara 8 were two varieties that produced through breeding program suitable to swampland, have relatively low productivity. The hybrid rice varieties, especially Mapan, yielded 10,184 kg/ha.

\section{Conclusions and suggestions}

1. The yield of several superior rice varieties in the swampy agro-ecosystem of the Mesuji Regency, Lampung Province was significantly different which depended on the adaptability of the varieties planted.

2. The lowest rice yield was obtained from the Inpara-2 variety (7.573 ton.ha ${ }^{-1}$ of Harvested Dry Grain - HDG) while the highest rice yield was from the Kebo variety (10.400 ton.ha- ${ }^{-1}$ HDG). To optimize rice production in an area, it is necessary to use superior rice varieties that have been adapted to the local area.

3. In the future the use of rice varieties with high yielding and adaptive in land with special specifications such as tidal swamp land, the selection of varieties should consider the adaptability of the varieties planted.

4. To achieve a high level of rice production, the use of superior varieties of hybrid rice and adequate input of production facilities is highly recommended, but in areas where farmers have limited conditions such as the ability to farm capital, use of inbred rice 
varieties such as Cilamaya Muncul, Inpara, and IR Nutrizinc is highly recommended because the production input required is quite low and this type of inbred rice can be used for next season's seed.

Acknowledgments. High appreciation is conveyed to Yuli Setyo Rahayu A.Md and Sukarto for all their assistance in carrying out field research activities. May it be a charity of worship by our Lord.

\section{References}

1. Indonesian Agency for Agricultural Research and Development, Peta zona agroekologi Provinsi Lampung skala 1:250.000 (Ministry of Agriculture, Jakarta, 2013)

2. Lampung Province Central Burear of Statistics, Area of rainfed rice fields in Lampung, in Lampung Province in Numbers (Bandar Lampung, Lampung, 2019)

3. B. Hafif, Keragaan lahan sub-optimal dan perbaikan produktivitas melalui kebijakan daerah di Lampung, in Seminar Nasional Inovasi Teknologi Pertanian (2013)

4. Slameto, Keragaan Produksi Padi Sistem Ratun Pada Lahan Pasang Surut Di Kabupaten Mesuji, in Prosiding Seminar Nasional Percepatan Alih Teknologi Pertanian Mendukung Revitalisasi Pertanian dan Pembangunan Wilayah, Denpasar, 5 September 2017, Badan Litbang Pertanian, p 769-776 (2018)

5. I.P.G. Widjaja-Adhi, D.A. Suriadikarta, M.T. Sutriadi, I.G.M. Subiksa, I.W. Suastika, Pengelolaan pemanfaatan dan pengembangan lahan rawa, in Sumber Daya Lahan Indonesia dan Pengelolaannya, Pusat Penelitian Tanah dan Agroklimat, p 127-164, Bogor, West Java (2000)

6. I.P.G. Widjaja-Adhi, T. Alihamsyah, Pengembangan Lahan Pasang Surut: Potensi, Prospek dan Kendala Serta Teknologi Pengelolaannya Untuk Pertanian, in Prosiding Seminar Himpunan Ilmu Tanah Jawa Timur, 18 Desember 1998, Malang, East Java (1999)

7. I.P.G. Widjaja-Adhi, Potential, Opportunities and Constraints Extension of Agricultural Area in Tidal Swamp Kalimantan and Irian Jaya, In Seminar Perluasan areal Pertanian di KTI, 7 - 8 November 1995, Serpong, Banten (1995)

8. I.P.G. Widjaja-Adhi, K. Nugroho, D.A. Suriadikarta, A.S. Karama, Sumberdaya lahan rawa, potensi, keterbatasan dan pemanfaatan. risalah. pernas pengembangan pertanian di lahan rawa pasang surut dan lebak (Badan Litbang Pertanian, 3-4 Maret 1992, Cisarua, West Java, 1992)

9. Indonesian Agency of Agricultural Research and Development, Prospek dan pengembangan komoditas pertanian: tinjauan aspek sumberdaya lahan, Badan Penelitian dan Pengembangan Pertanian, Kementerian Pertanian, Jakarta (2013)

10. S. O. Adigbo, M. O. Olojede, P. J. C. Harris, O. Ajayi, Exp. Agric. 48, 4 (2012)

11. Food and Agriculture Organization (FAO), Revitalizing rice ratooning to reduce risk and impact during hazard-prone months in the Bicol region, Philippines, http://www.fao.org/3/CA3047EN/ca3047en.pdf, 10 Oktober 2014 (2013)

12. D. R. Pinera, A. A. Martin Jr., J. Crop. Sci. 36, 1 (2011)

13. J. C. Flinn, M. D. Mercado, Economic perspectives of rice ratooning, In Rice Ratooning (Los Banos (PH), International Rice Research Institute, 1988)

14. F. C. Oad, M. A. Samo, Z. U. Hassan, P. S. Cruz, N. L. Oad, Int J. Agri. Biol. 4, 2 (2002)

15. B. S. Susilawati, B. S. Purwoko, H. Aswidinnoor, E. Santosa, J. Agron. Indones. 38, 3 (2010)

16. P. H. Sinaga, Trikoesoemaningtyas, D. Sopandie, H. Aswidinnoor, Asian J. Agric. Res. 8, 5 (2014) 
17. P. Sasmita, Satoto, Rahmini, N. Agustiani, D.D. Handoko, Suprihanto, A. Guswara, Suharna, Deskripsi varietas unggul baru padi (Badan Litbang Pertanian Press, Jakarta, 2019) 